\title{
The Poetic Negotiations of a Gentleman Radical: Ernest Jones and the "Mighty Mind"
}

\author{
SIMON RENNIE
}

I am pouring the tide of my songs over England, forming the tone of the mighty mind of the people. ${ }^{1}$

These words from an October 1846 diary entry of Ernest Charles Jones as the movement was still growing accustomed to the appearance in its ranks of the godson of the Duke of Cumberland (by then King Ernest of Hanover). The first thing that strikes the modern reader of the above quotation is the privilege attributed to the position of the author. The relative status of the author is only enhanced by the description of the imagined collective readership as "the mighty mind." Descriptions of "pouring ... over" and "forming the tone" are unequivocal in their indication of influence and agency, reflecting the Chartist perception of the active role of poetry within the movement formed prior to Jones's involvement around a favored group of poets including Allen Davenport, ${ }^{2}$ Benjamin Stott, ${ }^{3}$ and Thomas Cooper. ${ }^{4}$ But in addition to its political function, Jones's popular poetry throughout his Chartist involvement served to negotiate the complex issues arising from the forging and maintenance of a relationship between a young man whom Feargus O'Connor described as "a sprig of the aristocracy," and the largely working-class membership of a mass political movement. This article examines the role played by Jones's poetry in these negotiations from his introduction to the movement in 1846 to his elevation to the role of Chartist leader in the $1850 \mathrm{~s}$.

\section{Northern Star Poetry (1846)}

From the beginning of his Chartist career Jones negotiated a relationship with his audience through his poetry (in conjunction with his skills as an orator and a journalist) that either emphasized or diminished his social difference in order to suit the particular issue being addressed. The quasi-fictitious nature of the poetic voice served as a filter through which Jones could communicate ideas to his audience 
from varying social standpoints. The speaker of "The Two Races" (Northern Star 12 September 1846) uses the privilege of familiarity with the remnants of the pre-industrial ruling class, the "Gentlemen of England" (1. 1), to plead for their assistance in the battle against a growing industrialist hegemony; the relatively long poem "England's Greatness" (Northern Star, 7 April 1846) reflects its writer's level of education in its geographical expansiveness. But Jones's introductory poem, published in the Northern Star on 16 May 1846, was "Our Summons," the first of four pieces that summer whose titles begin with that defiantly self-conscious first person plural. From the outset Jones attempts to establish himself as part of the democratic cognoscenti as his first poems perform multiple functions as letters of introduction, curriculum vitae, and political rallying cries.

"Our Summons," along with "Our Destiny," "Our Warning," and "Our Cheer," is a quintessential Chartist lyric, undoubtedly the kind of work John Saville had in mind when he stated in his biographical introduction to Ernest Jones: Chartist that "much of his [Jones's] poetry was never more than adept versification." However, attentive reading of Jones's early Chartist works reveals undercurrents of meaning that belie the apparent simplicity of their construction. Taken as a group, the four "Our ..." poems document the subtly changing relationship between Jones and his largely working-class audience in the early months of his Chartist career.

Despite the inclusivity of its title, the mode of address in "Our Summons" separates the speaker from the addressees: the "men of honest heart" (1. 1). The poem is intensely class-conscious, relying on Jones's characteristic inversion of the relative nobility of the upper and lower strata of social class as the basis for its moral vision:

'Tis not to dig the grave,

Where the dying miner delves;

'Tis not to toil for others

But to labour for yourselves.

And nobler coin will pay you,

Than Kings did e'er award

To the men, they hired to murder,

The brothers they should guard.

No glittering stars of knighthood,

Shall soil your simple vest-

But the better star of honour

Brave heart in honest breast. 
No changing Norman titles,

To hide your English name-

But the better one of freemen,

With its blazoning of fame. (11. 21-36)

Jones, the trained barrister, compares the imperative of Chartist political action to a "summons." Although the work's title declares it be part of a communitarian discourse, its speaker is not included in the political relationships detailed by the second person address but represents either an omniscient narrator or Jones himself, assuming a pose of disinterestedness. The tension between the modes of address of the title and the body of the poem suggest the tentative positioning that a young man in Jones's situation might have felt obliged to adopt, drawn to a struggle between two classes of which he had little experience.

Something significant happens halfway through "Our Destiny," the second poem of the group. An epiphanic volta switches the mode of address mid-poem from second person to first person, deftly inserting the speaker into the social sphere of the poem. Jones achieves this by masking his sleight-of-hand in the fervid register of religious revelation. Where the iambic "Our Summons" has a bouncing, song-like rhythm, "Our Destiny" begins with heavy trochees and drawn-out anapests, and this, along with the liberal use of exclamation marks, gives the poem's opening an urgent, insistent feel. The mode of address in the first two stanzas is a continuation of the second person of "Our Summons," with the addition of "ye," the archaic second person plural, enhancing the millenarian register of the poem:

Labour! labour! labour! toil! toil! toil!

With the wearing of the bone and the drowning of the mind;

Sink like shrivelled parchment in the flesh-devouring soil;

And die, when ye have shouted it till centuries shall hear!

Pass away unheeded like the waving of the wind!

Build the marble palace! sound the hollow fame!

Be the trodden pathway for a conqueror's career!

Exhale your million breathings to elevate one name!

And die, when ye have shouted it till centuries shall hear! (11. 1-9) ${ }^{7}$

The first line's hammer-like repetitions are abandoned for the ensuing stanzas, but it nevertheless begins an interlocking rhyme scheme that links the first and second stanzas. The flurry of exclamation marks lends a desperate mood to the ironic encouragement to continue working for the benefit of a privileged few. The volta falls between the two following stanzas which introduce a divine justification 
for political action; "ye" is replaced by "us" and the speaker becomes part of the second half of the poem's response to the first half:

"By right divine we rule ye. God made ye but for us!"

Thus cry the lords of nations to the slaves whom they subdue.

Unclasp God's book of nature-its writings read not thus!

Hear! tramplers of the millions!-Hear! benders to the few!

God gave us hearts of ardour-God gave us noble forms-

And God has poured around us his paradise of light!

Has he bade us sow the sunshine, and only reap the storms?

Created us in glory, to pass away in night? (11. 10-17)

The repetition of the term "Hear!" in the thirteenth line echoes Shelley's similar use of the term as a refrain in the psalmic "Ode to the West Wind": "Destroyer and preserver; hear, $\mathrm{O}$ hear!" (1.14). Jones employs the evangelical power of the term to provide the need for a self-justifying response that includes the speaker in the number of the oppressed "millions." The speaker becomes part of the divinely elected band whose message of change is echoed by the elemental forces of the natural world, and accompanied by an implicit threat:

No! say the sunny heavens, that smile on all alike;

The waves, that upbear navies, yet hold them in their thrall;

No! shouts the dreadful thunder, that teaches us to strike

The proud, for one usurping, what the Godhead meant for all.

No! no! we cry united by our suffering's mighty length:

Ye-ye have ruled for ages-now we will rule as well!

No! no! we cry triumphant in our right's resistless strength;

We-we will share your heaven-or ye shall share our hell! (11. 18-25)

The speaker's shift from observer to participant is disguised by the magnitude of the righteous indignation the poem expresses. The repeated exclamatory anaphoric negatives that punctuate the final lines of the poem bring an even greater emphasis to an already emphatic piece. The repetition of the term "we" in the final line, in oppositional relation to the repetition of "ye" two lines earlier (which now denotes the oppressors rather than the oppressed), reinforces the speaker's association with the poem's protagonists.

The third of the Northern Star "Our ..." poems, "Our Warning" is unequivo$\mathrm{cal}$ in its mode of address. "Ye" refers to the ruling class of the country, and "we" are a potential working class army, recruiting from every corner of the British Isles: 
Ye lords of golden argosies!

And Prelate, prince, and peer;

And members all of Parliament,

In rich St. Stephens, hear!

We are gathering up through England,

All the bravest and the best;

From the heather-hills of Scotland,

To the green Isle of the West.

From the corn field and the factory,

To the coal-belt's hollow zone;

From the cellars of the city,

To the mountain's quarried stone. (11. 1-12) ${ }^{9}$

There is little doubt that the call to the ruling class contained in the first stanza would have had more resonance for the readers of the Northern Star who knew that Jones had been associated with that social sphere. Jones's condemnation of the establishment was all the more effective for him having formerly been part of it. These poems were published during Jones's rapid rise through the political ranks of the Chartist movement, and it was at this point that Jones's poetry began to enjoy a closer relationship with his political life. Jones's most recent biographer, Miles Taylor, has written that "Jones's poetry ... catapulted him from relative obscurity into the Chartist leadership." ${ }^{10}$ But throughout Jones's political career it must have been an advantage to be able to make political points through the medium of poetry, in the guise of various poetic voices. In "Our Warning" the perennial Chartist issue of "physical force v. moral force" is addressed. Saville contends that Jones "always ... refused to accept what he considered to be the false dilemma between moral and physical force, responsible for so much of the disunity of the movement since its early years" (Saville, p. 22). In his speeches and in his poetry violence was a last resort threat, yet the threat was real and consistently forceful:

We seek to injure no man;

We ask but for our right;

We hold out to the foreman

The hand that he would smite!

And, if ye mean it truly,

The storm may yet be laid, 
And we will aid you duly, As brothers brothers aid;-

But, if ye falsely play us, And if ye but possess

The poor daring to betray us,

Not the courage to redress;

Then your armies shall be scattered,If at us their steel be thrust,And your fortresses be battered, Like atoms in the dust!

And the anger of the nation Across the land shall sweep, Like a mighty Devastation Of the winds upon the deep! (11. 21-40)

The message of peace in the sixth stanza ("we seek to injure no man") is conditional upon the behavior of the opposition, but the proximity of violence is implied by the fact that "the storm may yet be laid" [my italic]. The numerical advantage of the working class is used in the last two stanzas as an opportunity to employ Old Testament language of battle and destruction; "the anger of the nation" seemingly sufficient to produce an inevitable victory. The lack of an apparent material destructive agent or method recalls the collapse of the walls of Jericho in the penultimate stanza, while the imagery of the wind's effect on the ocean in the last stanza is almost certainly derived from the third canto of Shelley's "Ode to the West Wind": "The sea-blooms and the oozy woods which wear / The sapless foliage of the ocean, know / Thy voice, and suddenly grow grey with fear, / And tremble and despoil themselves" (3. 39-42). Shelley's elemental representation of revolutionary historical cycles was prominent in the public consciousness of the time; although first published in the Prometheus Unbound volume of 1820, it, along with most of Shelley's work, benefitted from Mary Shelley's championing and collecting of his oeuvre in the late $1830 \mathrm{~s}$ and early 1840s. Although there is a clear philosophical discrepancy between Shelley's pacifism and Jones's more equivocal attitude to the use of violence for revolutionary or reformist means, the depiction of the forces of change as natural phenomena served them both. For Jones, the Shelleyan tropes of naturalization of revolutionary action which were frequently used in his work not only assured his readers of probable success in their political pursuits, but 
absolved them of any moral censure by aligning their actions with an historical inevitability. Jones had certainly visited this area before in the natural theology contained in his translations of German Romantic poets including Ernst Moritz Arndt and Ludwig Ühland.

By the fourth poem in the "Our ..." series, "Our Cheer," Jones has, by the accretion of poetic familiarity, built up the confidence to criticize his readership and consequently steps outside of the action again. But this time the second person address is infused with a register of patriotic outrage:

My countrymen! why languish

Like outcasts of the earth,

And drown in tears of anguish

The glory of your birth?

Ye were a free-born people

And heroes were your race:

The dead, they are our freemen,

The living-our disgrace! (11. 1-8) ${ }^{11}$

It is extraordinary testament to the regard with which Jones was held by the Northern Star readership at this time, just a few months after his introduction to the Chartist movement, that he could berate his new audience in such vehement terms without damaging his political and poetic reputation. Despite the coalescent element of the Chartist political cause, the complex nature of this audience must still have been largely imagined by Jones, and its probable response would have been largely unknown. It is possible that poems such as this operate by a diffusion of censure, whereby each individual reader considers the poem to be primarily addressed to others, but nevertheless is affected by the message it imparts. There is also an element of "good cop/bad cop" in the focal shifts employed by the poem. The opening stanzas of "Our Cheer" at once denigrate the slavish behavior of the working class while elevating their status through the use of terms including "glory," "free-born," and "heroes." But as the poem continues the aggressive element intensifies: the last five stanzas of the poem pile religious, social, patriotic, sexual, and historical pressure on the readership to encourage decisive political action:

He shall not be a Briton

Who dares to be a slave!

An alien to our country!

And a mockery to the brave! 
Down with the cup untasted!

Its draught is not for thee.

Its generous strength were wasted

On all, but on the free!

Turn from the altar, bondsman!

Nor touch a British bride!

What? Wouldst thou bear her blushing

For thee at thine own side?

Back from the church door, craven!

The great dead sleep beneath,

And liberty is graven

On every sculptured wreath.

For whom shall lips of beauty,

And history's glories be?

For whom the pledge of friendship?

For the free! the free! the free! (11. 21-40)

The inclusive and often celebratory nature of much Chartist poetry is revealed here to contain underlying elements of exclusion and threat. The individual reader is presented with a form of coercive interpellation: the poem details the social consequences of a lack of self-identity as a Chartist. Unusually, acceptance of the role of poetic addressee in this case leads to a loss of identity as defined by the community. The favored position of the reader is beside the poem, castigating those who do not fully support the Chartist cause. Political exclusion is equated with sexual, religious, and social exclusion.

Within these poems' over-riding concerns with inclusion, their privileging of plural terms, and their gradual positioning of the author within the imagined readers' community, it is possible to read elements of the social anxiety that a man in Jones's situation might have felt. By disturbing the equilibrium of a highly stratified Victorian society, Jones's renegade behavior had left him (and his family) vulnerable to similar levels of social exclusion that his poetry prescribes for those who do not support the Chartist cause. Viewed in this light, the aggression identified in some of these poems can be seen as part of a strategy of deflection, or even, in more explicitly psychoanalytic terms, a displacement of anxiety. Jones's poetry in this initial Chartist period appears an attempt, through language, to will into being a relationship with his audience. In a most concrete way, language becomes, in Kenneth Burke's phrase, "symbolic action." 12 The 
linguistic repetition of the author's inclusion in his readers' community through the terms "we," "us," and "our" initiates and potentially consolidates a process of real social inclusion. The gradual nature of the poet-figure's absorption into the Chartist body in these early Northern Star pieces perhaps reflects Jones's anxiety that his entry into Chartism from a relatively "superior" social position should not be seen as coercive.

\section{Prison Poetry (1848-1850)}

After giving a speech to a crowd of several thousand Chartist sympathizers in Bishop Bonner's Fields in East London, in which he suggested that the current Home Secretary and Prime Minister should be deported, Jones was arrested. In July 1848 , amid the fervid atmosphere of a summer of European revolution and alongside many other Chartists, he was sentenced to two years imprisonment for seditious speech-making. This was not the kind of relatively genteel imprisonment that James Leigh Hunt (1784-1859) had experienced a generation before for defaming the Prince Regent in the pages of the Examiner in 1813. Jones was part of a potentially revolutionary working-class movement and served his time in the harsh conditions of the Westminster House of Correction, commonly known as Tothill Fields Prison, which had recently been built in the then modern "Panopticon" style. For significant periods of his sentence silence was enforced, he was isolated from his fellow prisoners, and he was denied communication with the outside world. Twelve of Jones's fellow prisoners died during a cholera outbreak in August 1849 (including Alexander Sharp, Jones's fellow speaker at the Bishop Bonner's Fields meeting), and Jones himself suffered serious ill health during the course of his incarceration.

In Lyric and Labour in the Romantic Tradition, Anne Janowitz suggests that the poetry Jones composed in prison saw a consolidation of his poetic voice that included an expression of increased identity with, and through, the Chartist body:

Jones's poetry prior to his imprisonment in 1848 engages chiefly with the genres of the Chartist hymn and song, in which he aimed to imagine and lyricise the experience of the group struggle, modified by his own steeping in the lyricism of romantic solitude. His prison poetry moves towards defining a collective subjectivity and identity from an opposing source, his individual experience in jail. ${ }^{13}$

This move toward definition would suggest an integration of poetic themes, genres, and voices but Jones's post-prison poetry saw, if anything, a fragmentation of his poetic output into the constituent voices of lyric Romanticism, collective hymnody, satirical social commentary, and visionary epic. Ronald Paul has noted that: 


\section{$66 /$ VICTORIAN POETRY}

One of the ironies of Jones's development is that, while his political ideas after his release from prison gravitated more and more towards socialism (influenced by his close co-operation at this time with Marx and Engels), his poetry began losing much of its immediate popular accessibility. ${ }^{14}$

Although Jones may have emerged from prison with his Chartist identity reinforced by experience and reputation, conversely, his poetry underwent a process of diffusion, so that, in comparison with the relative homogeneity of his Northern Star poetry (1846-1848), it becomes increasingly difficult to describe Jones's post- 1850 "poetic voice." Apart from poetry composed immediately prior to his release which appears to represent a conscious return to his pre-prison poetic style, Jones's prison poetry suggests the influence of the overwhelming effects of isolation, and the plight of fellow Chartists, inside or outside of prison, can scarcely be seen to figure at all. If Jones's most famous post-prison lyric "The Song of the Low" (1852) can be viewed as the supreme example of his talent for "defining a collective subjectivity," then there is little in his prison poetry that pre-figures it. Indeed, Jones's grasp of a collective subjectivity, his ability to express the needs and wants of the Chartist "we," could already be said to exist fully-formed in Northern Star poems including "The Working-Man's Song" (5 January 1847), and “Onward" (7 October 1847). This study finds that, for the most part, prison represents a poetic interlude in Jones's career, with explorations of his own imagination and struggles with isolation taking precedence over the kind of public engagement that typified his poetry in the two years before his arrest. Jones made political capital from his experience in jail, and the presentation of his prison poetry was part of that process, but the poetry itself offers little evidence of an enhanced engagement with the Chartist body.

Composed in July 1848, in the first month of Jones's imprisonment, "Bonnivard," a short poem of four quatrains, seems to represent an early attempt at bravado in the face of the prospect of incarceration, a kind of emotional pre-emptive strike. François Bonivard (1496-1570) was a celebrated Swiss patriot whose imprisonment was the inspiration for Byron's The Prisoner of Chillon (1816). The heroic nature of the protagonist's resistance to and survival of the prison experience would suggest that the poem represents a form of literary wish-fulfillment:

To Chillon's donjon damp and deep,

Where wild waves mount eternal guard,

Freedom's vigil long to keep,

They dragged our faithful Bonnivard.

Within their rocky fortress held,

They thought to crush that captive lone! 
That captive left their rock, unquelled, Altho' his foot had worn the stone.

They hoped his gallant heart to slay, And o'er it bound their chain accurst: 'Twas not his gallant heart gave wayIt was the chain that broke the first.

O'er Chillon's donjon damp and deep, Where wild waves mount eternal guard, Oblivion's ivied fingers creep,But all the world loves Bonnivard. (11. 1-16) ${ }^{15}$

If Jones is to be associated with Bonivard through literary figuring then the use of the affectionate possessive "our" to describe the protagonist in the fourth line perhaps strays too far into the realm of personal heroic fantasy. And yet the poem's theme of eventual victory through resistance might also reflect perennial Chartist concerns regarding the resilience of their members in the face of successive political setbacks. Bonivard's acquisition of fame and universal affection is not in spite of his imprisonment but partly because of it. The opposing terms in the last two lines are "love" and "oblivion," whose "ivied fingers" seem somehow integral to the process of eventual victory. Without the possibility of obscurity and abandonment, fame and victory are either unattainable or not worth attaining, just as in many approaches to Christian philosophy, there is no possibility of a spiritually worthwhile faith without the necessity of doubt which must be overcome.

Another of Jones's prison poems, "A Prisoner's Night-Thought," written in August 1848 and also consisting of four quatrains (although in iambic pentameter rather than the iambic tetrameter of "Bonnivard"), is an altogether darker, perhaps more emotionally authentic vision of the prison experience. Its title almost certainly refers to Edward Young's nine-part work in blank verse, The Complaint, or Night Thoughts (1742-1745), with which Jones may have been familiar during his schooling in the German states-Young's poetry was particularly popular there and was known to have influenced the young Goethe. ${ }^{16}$ Possibly reflecting a reaction to the cumulative effect of the relentless realities of the daily routine of prison life, the first stanza sets a register of resigned weariness that resists even the rather melodramatic conclusion of the work. With his characteristically explicit use of language, Jones does not shy away from use of the term "martyr," but an incipient sadness pervades this exploration of the heroic narrative arc. Gone is the fictional mask of "Bonnivard," this is a lyrical exploration of a heroism that, though dramatic, appears rooted in the real and in the present: 
My life is but a toil of many woes, And keen excitement, wearing to the core;

And fervently I hope an hour's repose, My duty done, and all my warfare o'er.

Loud shouts have beaten on my tingling brain; Lone prisons thrilled the fevered thread of life; The trophies perish-but the wrecks remain! And burning scars survive the dizzy strife.

Oh! 'tis a dreadful war, for one to wage, Against deep-rooted prejudice and power; Crush, in one life, the seeds of many an age, And blast black centuries in a single hour!

Who dares it, throws his life into the scale,Redemption's voluntary sacrifice:

His hope-to be a martyr, should he fail, Or, at best, to conquer-as he dies! (11. 1-16)

By eschewing the optimism of Jones's earlier Chartist poetry, "A Prisoner's NightThought" interrogates the nature of heroism and martyrdom with a previously unexplored psychological honesty. Indeed, the depth of the poem's pessimism is such that even the potentially uplifting conclusion offered by the conquest that features in the final line is counteracted by the specter of accompanying death.

A sense of community is completely absent from this poem, and the italicization of "one" in the seventh line is suggestive not just of the intensely personal nature of the struggle of the speaker, but perhaps that, in the Chartist context, community itself is being destroyed by this series of custodial punishments. The absence of print, or even oral, culture in Tothill Fields prison has the effect of disrupting any sense of what Benedict Anderson terms an "imagined community." As Anderson writes of Biblical depictions of prison, "they are never imagined as typical of this or that society. Each, like the one where Salome was bewitched by John the Baptist, is magically alone." ${ }^{17}$ This view of prison as a spatial and societal "other" might seem to contradict Foucault's conception of the "carceral continuum" which "extends without interruption from the smallest coercions to the longest penal detention," ${ }^{18}$ but in life, as in poetry, the difference depends on the point of observation. Foucault also suggests that prison is at the apex of a "carceral pyramid" (p. 302); perhaps the best view of a mountain is not from its peak. 
In "A Prisoner's Night-Thought" isolation leads to a sense of bitterness and resignation, but personal resolve is ultimately not weakened. In effect, the individual prisoner, divided from the communal force of the Chartist body in the most literal and physical of ways, is made to feel the full weight of the political pressure ranged against him. As though to emphasize the total disruption that prison inflicts upon the prisoner's life, there is a disruption of the rhythm of the poem through the use of polysyllabic terms in the fourteenth line. To describe imprisonment as "redemption's voluntary sacrifice" operates at the wider political level in that it is a poetic reclamation of autonomy under conditions of extreme restraint, but the use of the term "redemption" is perhaps autobiographical in Jones's case, referring to the residual guilt of a previous life of privilege. The poem itself is partially redeemed from its uncharacteristically dark vision of political martyrdom by being framed as a "night-thought": a waking dream that exposes a perhaps untypical vulnerability.

The twenty-four short poems that Jones produced in prison were published as a group in the fourth issue of his magazine Notes to the People (1851-1852). They document a journey of personal endurance against isolation and ill-treatment, indeed Jones refers to them as a "psychological table" in his introduction to the group, but that endurance is only belatedly related to the Chartist body, or even to Jones's fellow prisoners. There are some oblique references to political constancy-"Prison Fancies" (May 1849) declares "let me ne'er cease to cherish / the truths I have so fondly held" (11. 17-18)-but for the most part the poems represent a return, admittedly intensified by personal experience, to the lyrical Romanticism of the self that typified Jones's pre-Chartist output which was published in conservative newspapers including the Morning Post and the Court Journal in the early 1840s. Poems including "The Garden Seat" (July 1849) and "The Prisoner's Dream" (September 1849) represent attempts to consolidate the identity of the individual prisoner through imaginative excursions into idyllic rural landscapes; "poesy" and "fancy" are their subjects, not freedom or political solidarity. It is only in the spring of 1850 , as Jones is preparing for his release in July of that year, that his poetic voice turns once more to the plight of his fellow Chartists, and to the song-like rhythms which characterized much of his Northern Star poetry. "Easter Hymn" utilizes the lurid imagery of the Passion of Christ to represent the political martyrdom of the Chartist body:

Crucified, crucified every morn;

Beaten and scourged, and crowned with thorn;

Scorned and spat on, and drenched with gall;

Brothers! How long shall we bear their thrall? (11. 1-4: Notes to the People

Vol. 1, p. 69) 
While Jones's imprisonment lends biographical authenticity to this poem's account of communal suffering, its poetic or thematic relation to the preceding twenty-one prison poems is minimal; the lack of continuity is striking. Jones's suffering for his beliefs has entitled him to address his fellow Chartists as "Brothers!," but this intimacy has been earned by the fact of his imprisonment, not through a continuous process of poetic negotiation. When Jones has no immediate audience, he fails, or refuses, to imagine it. For almost two years between the relative glories of two Chartist careers which were predicated partly on poetic communication with the British working class, Jones's poetry functioned as an introspective consolidation of his own identity.

\section{Post-Prison Poetry (1851-1860)}

On his release from prison in July 1850 , Jones rapidly established himself once more as a major voice in Chartism (in an admittedly much-diminished movement in terms of mass membership), eventually taking control as the de facto leader after the psychological decline of Feargus O'Connor (1794-1855). His establishment and editorship of the Notes to the People magazine (with contributions from Marx and Engels among others) enabled him to articulate his political vision for the future of the Chartist movement and to continue to define his relationship with its largely working-class membership. In the seventeenth issue of the periodical a poem appeared entitled "The Prisoner to the Slaves," which might be read as an attempt to re-imagine, in more explicitly political terms, the period of Jones's incarceration:

From my cell, I look back on the world-from my cell

And think I am not the less free

Than the serf and the slave who in misery dwell

In the street and the lane and the lea.

What fetters have I that ye have not as well,

Though your dungeon be larger than mine?

For England's a prison fresh modelled from hell,

And the jailors are weakness and crime. (1l. 1-8; Notes to the People Vol. 1, p. 339)

If this is the poem that Jones wished he had written in prison, then it is also the poem which most coherently anticipates Foucault's concept of the "carceral continuum." The conflation of the political situations of the individual prisonersubject and the disenfranchised working class approaches a conception of a society 
where "prison continues, on those who are entrusted to it, a work begun elsewhere, which the whole of society pursues on each individual through innumerable mechanisms of discipline" (Foucault, p. 302).

But Jones's repetition of the phrase "from my cell" in the first line suggests a similar ontological perspective to the personal primacy in the relationship between poet and audience indicated by the diary quotation which opens this essay. Although the relationship between "the prisoner" and "the slaves" is nominally equal, it is the former who embodies the suffering of the latter, and whose martyrdom defines the political relationship between opposing classes: Britain is characterized as a "prison," not as a slave plantation. By the final sixth stanza the Chartist "we" has returned, diametrically opposed to the "they" whose hegemony is recognized and destabilized by the poem:

They shall hear us again on the moorland and hill, Again in street, valley and plain:

They may beat us once more-but we'll rush at them still-

Again-and again-and again! (11. 21-24)

Within the imaginative progression of this single post-prison lyric Jones achieves what Janowitz claims of him by "mov[ing] towards defining a collective subjectivity and identity from ... his individual experience in jail," conjoining personal bitterness to widespread political dissatisfaction in order to foment instability and instigate resistance (p. 185). While there is a geographical inclusivity in the identification of revolutionary sites as "moorland," "hill," "street," "valley," and "plain," there is also an unequivocal threat of violence in the image of a Chartist body willing to repeatedly "rush at them still." The equation of working-class political oppression with the physical oppression suffered by Jones during his imprisonment becomes part of the justification for revolutionary violence.

Whether the more explicitly stated threat of violence in "The Prisoner to the Slaves" emerged from personal bitterness or from the ideological shifts growing from the development of Jones's post-prison associations with Marx and Engels, this expression was enabled by his elevation to a higher position within the Chartist movement, which diminished the need for negotiation with the "moral force" wing of the movement. But poetically, other influences were at still at work. As indicated earlier, in spite of Shelley's oft-stated pacifism, his writings proved a profound influence on the poetry of Ernest Jones. Shelley was eulogized in the pages of the Chartist press for his support of democratic principles in his essays and poetry, and for his relinquishment of the privileges of his birthright in order to assume the role of a radical poet. In many ways, Shelley 


\section{2 / VICTORIAN POETRY}

was perceived by Chartists as the archetypal "gentleman radical," and it is not inconceivable that Jones identified himself with his poetic predecessor. At the end of his three-page-long introduction to The New World (whose eventual title, The Revolt of Hindostan, deliberately alludes to Shelley's The Revolt of Islam [1818]), Jones addresses the American people:

Free citizens of the republic! my country has been called the "Ark of Freedom"-but in yours I see its Ararat, and to you, at whose hands Shelley looked for vindication and immortality, a humbler bard now dedicates his work. (Notes to the People Vol. 1, p. 4)

For Jones, and many other Chartist poets, Shelley was the radical poetic yardstick against which to be measured. The series of works that Shelley produced in response to the Peterloo massacre of 1819 were particularly influential, partly because of their song-like nature. These demotic, or as Shelley termed them, "exoteric," poems included "The Mask of Anarchy," "England in 1819," and "Men of England: A Song." Jones used the latter poem as the basis for his most anthologized work, "The Song of the Low." The fifth stanza of Shelley's work emphasizes capitalism's exploitation of various trades:

The seed ye sow, another reaps;

The wealth ye find another keeps;

The robes ye weave, another wears;

The arms ye forge, another bears. $(11.17-20)^{19}$

After an opening chorus which acts as a refrain, Jones takes each of these trades (agriculture, mining, textile, and arms) and creates a stanza from each of them, retaining the same order, but he inserts the building trade as the subject of the fourth stanza, reflecting the urban construction boom of the mid-nineteenth century. "The Song of the Low" continues Shelley's theme of exploitation but adds a tone of ironic humor:

We're low-we're low-we're very very low,

As low as low can be;

The rich are high-for we make them so-

And a miserable lot are we!

And a miserable lot are we! are we!

A miserable lot are we!

We plough and sow-we're so very very low,

That we delve in the dirty clay, 
Till we bless the plain with the golden grain,

And the vale with the fragrant hay.

Our place we know-we're so very low,

'Tis down at the landlords' feet:

We're not too low-the bread to grow,

But too low the bread to eat.

We're low, we're low, etc. (1l. 1-15) ${ }^{20}$

"The Song of the Low" diverges from the philosophies that underpin Shelley's poetry in the fifth stanza (or verse, when sung). Jones does not miss the opportunity to highlight the irony of a social class making the weapons that are used by another class to oppress it. In Shelley's "The Mask of Anarchy," an imaginary Peterloo crowd is urged to use passive resistance when confronted with violence:

"With folded arms and steady eyes,

And little fear, and less surprise,

Look upon them as they slay

Till their rage has died away.

"Then they will return with shame

To the place from which they came,

And the blood thus shed will speak

In hot blushes on their cheek. (11. 343-350) ${ }^{21}$

Jones is altogether less forgiving, but chooses his words carefully:

We're low, we're low-we're very, very low,

And yet when the trumpets ring,

The thrust of a poor man's arm will go

Through the heart of the proudest king!

We're low, we're low-our place we know,

We're only the rank and file,

We're not too low-to kill the foe,

But too low to touch the spoil. (11. 61-69)

Jones's legal training probably made him aware that the wording of lines appearing to advocate regicide in his poem was ambiguous enough to be construed as referring to a foreign king being overthrown by a British army. The moment when the "trumpets ring" might represent a call to arms that is either patriotic or revolutionary; the subjects of this stanza might be soldiers or guerrillas. The sly humor of 
these ambiguities combine with ironic statements including "our place we know" and "a miserable lot are we" to form a confidential bond between the poet and the reader through the implication of shared knowledge and purpose. Jones's increased political maturity and sophistication is echoed in the more conscious complexity of his poetic voice. An important aspect of "The Song of the Low," and one the reasons for its continuous popularity as a song of protest, is that the collective identity articulated by it is at once broader and more specific than merely "Chartist." The kind of political consciousness insisted upon by Jones's Northern Star poetry is not a prerequisite to inclusion within the poem's sphere of sympathy, and yet the poem's systematic identification of industrial categories has the effect of interpellating the individual working-class reader-subject. At the same time, the poet-figure's apparent inclusion in the social stratum defined and celebrated by the work is registered through the frequency of the repetition of the term "we." Indeed, given that the piece's full version contains seventy-one instances of the term "we," "The Song of the Low" might also be thought of as a celebration of Jones's perception of his eventual inclusion within the ranks of the radical working class.

However, as Ronald Paul has noted, despite the success of "The Song of the Low" as a perennial expression of protest, Jones's post-prison poetry lost much of its popular appeal. The publication of the long visionary epic The New World (which had at least partly been composed in prison) in the pages of Notes to the People marked the beginning of a period in which Jones's poetry diffused into several genres and only occasionally felt the need to address a particular audience. Jones began once again to write poetry that, in John Stuart Mill's famous phrase, was intended to be "overheard" rather than "heard," alongside compositions that retained more or less explicit expressions of their author's political observations. With the collections The Battle-Day and Other Poems (1855) and Corayda: A Tale of Faith and Chivalry, and Other Poems (1860), Jones's post-prison poetic output broadened to include medieval epics, social satires, and the re-publication of pre-Chartist material which privileged Romantic solitude. The dissolution of the Chartist vision negated the need for specifically targeted poetic voice. Given that 1848 represented the last even partial success of Chartism as a mass movement, it might be said that Jones's eventual assimilation into the organization, in which his poetry played such an integral part, occurred several years too late.

The apparently sudden radicalization of the twenty-six year-old Ernest Jones has been the subject of much speculation by historians, but his early Northern Star poetry serves to illuminate some of the ways in which he negotiated an entry into a social environment with which he was singularly unfamiliar. The development of Jones's radical poetic voice can be charted through the "Our..." poem series as the 
speaker gradually positions himself within his own narrative and begins to address his audience with increasing confidence. While his reputation as an orator grew rapidly from his first involvement with the movement, it was the mass circulation of this popular poetry which largely consolidated his position as a central figure in what Mike Sanders has termed "the Chartist imaginary." ${ }^{22}$ Imprisonment cemented his political reputation even as the poetry he composed while incarcerated largely withdrew from the movement's concerns to explore the personal ramifications of political sacrifice. However, the assurance of the poetic voice in "The Song of the Low" reflects the political kudos acquired by Jones through his prison sentence and immediate return to the Chartist cause. The authentic experience of suffering expunged any lingering suspicions of trans-cultural tourism or political gloryseeking. And yet while it may have been the case that Jones's status as prisoner in effect brought him to a similar social level as many of those within his workingclass readership, he also retained the status of the gentleman radical, maintaining friendships with influential figures including Edward Bulwer-Lytton (to whom the Corayda collection was dedicated) and Benjamin Disraeli. ${ }^{23}$ Jones effectively gained "dual-citizenship," with something approaching full rights to associate himself with, and claim the benefits of, either camp. Indeed, the increased diversity of Jones's post-prison poetry began to reflect his multiple social identities. Although Chartism as a mass movement was effectively finished by the mid-1850s, Jones's association with reformist politics continued with his association with the more moderate Reform League. His bond with the British working class continued until his early death at the age of fifty (which some attributed to prison having permanently weakened his constitution), as he returned to legal practice and defended cases of perceived social injustice, industrial complaints, and radical activism. The many thousands who lined the streets for his funeral procession through Manchester in 1869 attested to the success of Jones's strategies of social negotiation, a large part of which were achieved through his poetry.

\section{Notes}

1 Ernest Jones Diary, 8 October 1846, Manchester County Record Office, MS. f281.89 $\mathrm{J} 5 / 30$.

2 Allen Davenport (1775-1846) was a shoemaker by trade who was the president of the East London Democratic Association and a supporter of the Chartist Land Plan. His first poetry was published in 1819 but his Northem Star poetry page debut ("Repeal and the Charter") was on 5 August 1843.

3 Benjamin Stott (1813-1850) was a bookbinder active in local radical politics in Manchester. He was a relatively prolific contributor to the Northern Star poetry pages with 


\section{$76 /$ VICTORIAN POETRY}

over twenty pieces published from 1841 , many of which were collected in the volume Songs for the Millions and Other Poems (1843).

4 Thomas Cooper (1805-1892) shared with Davenport an original trade of shoemaker and was Jones's predecessor as unofficial Chartist Laureate before falling out with the Chartist leadership in 1846. His long work in Spenserian stanzas, The Purgatory of Suicides (1845), was composed during a two-year prison term and is considered a major achievement of Chartist poetics.

5 John Saville, "Introduction," Ernest Jones: Chartist, John Saville, ed. (London: Lawrence \& Wishart, 1952), p. 20.

6 Ernest Jones, "Our Summons," Northern Star, 16 May 1846.

7 Ernest Jones, "Our Destiny," Northern Star, 11 July 1846.

8 Percy Bysshe Shelley, "Ode to the West Wind," Percy Bysshe Shelley: The Major Works, Zachary Leader and Michael O'Neill, eds. (Oxford: Oxford Univ. Press, 2003), pp. 412-414.

9 Ernest Jones, "Our Warning," Northern Star, 1 August 1846.

10 Miles Taylor, Emest Jones, Chartism, and the Romance of Politics 1819-1869 (Oxford: Oxford Univ. Press, 2003), p. 78.

11 Ernest Jones, "Our Cheer," Northern Star, 8 August 1846.

12 Kenneth Burke, Language as Symbolic Action: Essays on Life, Literature and Method (Berkeley: Univ. of California Press, 1966).

13 Anne Janowitz, Lyric and Labour in the Romantic Tradition (Cambridge: Cambridge Univ. Press, 1998), p. 185.

14 Ronald Paul, "In louring Hindostan': Chartism and Empire in Ernest Jones's The New World, A Democratic Poem," Victorian Poetry 39.2 (Summer 2001): p. 192.

15 Ernest Jones, Notes to the People, Vol. I, (London: J. Pavey, 1851), p. 63.

16 Derek Van Abbé, Goethe: New Perspectives on a Writer and His Times (London: Allen and Unwin, 1972), p. 44.

17 Benedict Anderson, Imagined Communities: Reflections on the Origins and Spread of $\mathrm{Na}$ tionalism (London: Verso, 1983), p. 30.

18 Michel Foucault, Discipline and Punish: The Birth of Prisons, trans. Alan Sheridan (London: Peregrine, 1977, Penguin, 1991), p. 303.

19 Percy Bysshe Shelley, "Men of England: A Song," Shelley: Poetical Works, ed. Thomas Hutchinson (London: Oxford Univ. Press, 1967), p. 572.

20 Ernest Jones, "Song of the Low," An Anthology of Chartist Literature, ed. Y. V. Kovalev, gen. ed. A. A. Elistratova (Moscow: Foreign Languages Publishing House, 1956), p. 174.

21 Shelley, "The Mask of Anarchy," Shelley: Poetical Works, p. 344.

22 Mike Sanders, The Poetry of Chartism: Aesthetics, Politics, History (Cambridge: Cambridge Univ. Press, 2009), p. 7.

23 For details of Jones's association with Disraeli, see G. J. Holyoake, Sixty Years of an Agitator's Life, Vol. II (London: Fisher Unwin, 1892), p. 250. 
Copyright of Victorian Poetry is the property of West Virginia University Press and its content may not be copied or emailed to multiple sites or posted to a listserv without the copyright holder's express written permission. However, users may print, download, or email articles for individual use. 